\title{
Production of pizza dough with reduced fermentation time
}

\author{
Obtenção de massa de pizza em tempo reduzido de fermentação
}

\author{
Simone LIMONGI ${ }^{1}$, Deise Rosana Silva SIMÕES² ${ }^{2}$ Ivo Mottin DEMIATE ${ }^{2 \star}$
}

\begin{abstract}
The aim of this study was to reduce the fermentation time of pizza dough by evaluating the development of the dough during fermentation using a Chopin ${ }^{\circ}$ rheofermentometer and verifying the influence of time and temperature using a $2^{2}$ factorial design. The focus was to produce characteristic soft pizza dough with bubbles and crispy edges and soft in the center. These attributes were verified by the Quantitative Descriptive Analysis (QDA). The dough was prepared with the usual ingredients, fermented at a temperature range from 27 to $33^{\circ} \mathrm{C}$ for 30 to 42 minutes, enlarged, added with tomato sauce, baked, and frozen. The influence of the variables time and temperature on the release of carbon dioxide (H'm) was confirmed with positive and significant effect, using a rheofermentometer, which was not observed for the development or maximum height of the dough $(\mathrm{Hm})$. The same fermentation conditions of the experimental design were used for the production of the pizza dough in the industrial process; it was submitted to Quantitative Descriptive Analysis (QDA), in which the samples were described by nine attributes. The results showed that some samples had the desired characteristics of pizza dough, demonstrated by the principal component analysis (PCA), indicating a $30 \%$ fermentation time reduction when compared to the conventional process.

Keywords: experimental design; volume; QDA; rheofermentometer.
\end{abstract}

\section{Resumo}

Este trabalho teve como objetivo a redução do tempo de fermentação de massa de pizza avaliando-se o desenvolvimento da massa durante a fermentação com emprego de reofermentômetro Chopin e a influência das variáveis tempo e temperatura em um planejamento fatorial $2^{2}$. A intenção foi produzir massa característica de pizza, com formação de bolhas, crocância nas bordas e maciez no centro da massa verificando-se estes atributos pela metodologia de Análise Descritiva Quantitativa (ADQ). A massa foi preparada com os ingredientes usuais, fermentada a temperaturas variando de 27 a $33{ }^{\circ} \mathrm{C}$ por períodos de 30 a 42 minutos, alargada, adicionada de molho de tomate, assada e congelada. Por intermédio do reofermentômetro confirmou-se a influência das variáveis tempo e temperatura para liberação de gás carbônico (H’m) com efeito positivo e significativo, o que não ocorreu para desenvolvimento ou altura máxima da massa (Hm). As mesmas condições de fermentação do planejamento foram utilizadas para a produção de massa de pizza em processo industrial sendo submetida à Análise Descritiva Quantitativa (ADQ), onde as amostras foram descritas por nove atributos. Os resultados permitiram concluir que algumas amostras apresentaram características desejadas de massa de pizza demonstradas pela análise de componentes principais (ACP), indicando um tempo de fermentação reduzido em pelo menos $30 \%$ quando comparado ao processo convencional.

Palavras-chave: planejamento fatorial; volume; $A D Q$; reofermentômetro.

\section{Introduction}

Commercial interest in pizza, which is traditionally consumed in European countries, notably in Italy, has increased in Latin American countries and in the United States. Some reasons for market growth and consequent increase in industrial production are related with low cost of the product and ease of preparation for consumption (WANG et al., 2005).

The basic formulation of the dough includes flour, water, salt, sugar, and bakers' yeast (PINHO; MACHADO; FURLONG, 2001). The pizza dough is a significant fraction of the product and its appearance, texture, and taste are important attributes for its acceptance by consumers and identification (WANG et al., 2005).
Wheat flour is a structural component and an essential ingredient for obtaining the dough thus presenting a key role in the quality of baked foods due to its ability of forming extensive and elastic dough that retains carbon dioxide and expands (GAN; ELLIS; SCHOFIELD, 1995). The process steps responsible for gas retention and increased dough volume are: mixing and forming the dough, dividing and molding, fermenting, rolling, and baking. These steps are designed to develop the dough, forming a sponge-like structure, and stabilize the porous structure during baking (SCANLON; ZGHAL, 2001).

Received 13/7/2010

Accepted 15/6/2012 (004923)

${ }^{1}$ Programa de Pós-Graduação em Ciência e Tecnologia de Alimentos, Universidade Estadual de Ponta Grossa - UEPG, Av. Carlos Cavalcanti, 4748, CEP 84030-900, (Uvaranas), Ponta Grossa- PR, Brasil

2 Departamento de Engenharia de Alimentos, Universidade Estadual de Ponta Grossa - UEPG, Av. Carlos Cavalcanti, 4748, CEP 84030-900, (Uvaranas), Ponta Grossa - PR, Brasil,e-mail:demiate@yahoo.com

${ }^{*}$ Corresponding author 
Fermentation promotes aeration of the dough (DOBRASZCZYK; MORGENSTERN, 2003) through the generation of carbon dioxide in the aqueous phase of the dough that diffuses int the alveoli thus generating an excess internal pressure that forces expansion. The stabilization of the alveoli determines the structure and the volume of the dough (AUTIO; LAURIKAINEM, 1997).

The dough is usually prepared by the direct process using baker's yeast to ferment at temperatures between 23 and $26^{\circ} \mathrm{C}$ for a period of time required for leavening or the time necessary to raise the initial volume 2-5 fold before shaping the pizza discs (COPPOLA; PEPE; MAUREIELLO, 1998). Some authors indicate the fermentation temperature of $35^{\circ} \mathrm{C}$ for 60 minutes (CLARKE; FARRELL, 2000), $25^{\circ} \mathrm{C}$ for 6-8 hours (FORMATO; PEPE, 2005), and Wang et al. (2005), who produced pizza dough from mixtures of soybean and wheat flour, pre-cooked by extrusion, considered a shorter time of fermentation of $25{ }^{\circ} \mathrm{C}$ for 40 minutes. It is important to note that there is not a standardization of the pizza dough production method, and that it also reflects in the lack of identity for parameters as final product appearance, height, texture, and other important quality aspects. As written by Coppola, Pepe and Maureiello (1998), this kind of product is widely characterized by highly variable and often unsatisfactory quality.

With the popularization of pizza in relation to other baked products, it can be observed that the quality of its dough is characterized by high variability even though the majority of manufacturing methods are similar. It can be said that this is an area that remains poorly investigated (LARSEN; SETTER; FAUBION, 1993; COPPOLA; PEPE; MAUREIELLO, 1998) and that there are few studies published after the year 1990, despite the food industry growing interest in producing high quality pizza dough. Like other industrial processes, it must be continually improved in order to provide reduced cost and time.

This study aims to evaluate the fermentation process by measuring the change in volume of pizza dough (before shaping the pizza discs) using a rheofermentometer considering the influence of the variables time and temperature using a $2^{2}$ factorial design in order to reduce the fermentation time. Therefore, the objective is to produce characteristic soft, airy, crispy pizza dough evaluating these attributes by Quantitative Descriptive Analysis (QDA).

\section{Materials and methods}

\subsection{Experimental design for pizza dough production}

A $2^{2}$ complete factorial design with two factors (time and temperature of fermentation), two levels coded as -1 and +1 with a central point (coded as 0 ), and three repetitions was used for producing the pizza dough samples. Seven treatments were performed. The developing times and temperatures of the dough were 30,36, and 42 minutes and 27, 30 and $33{ }^{\circ} \mathrm{C}$, respectively. For the sensory analysis, three out of the seven runs were selected and identified as "A", "B", and " $\mathrm{C}$ " $\left(27^{\circ} \mathrm{C} / 42\right.$ minutes, $30{ }^{\circ} \mathrm{C} / 36$ minutes, and $33{ }^{\circ} \mathrm{C} / 42$ minutes, respectively), and these runs were chosen based on the best rheofermentometer results considering the complete temperature range tested.

The developing time and the temperature range tested were selected based on the industrial needs for frozen pizza production and considering the results of previous assays (data not shown). The temperature range is also well established in the literature for this type of leavened bread/pizza dough development.

\subsection{Preparing the pizza dough}

The ingredients of the pizza dough were based on the weight of flour (100\%). The base formulation was type 1 wheat flour fortified with iron and folic acid (BRASIL, 2005) (100\%), crystal sugar (around $4 \%)$, refined salt $(2 \%)$, soybean oil (3\%), baker's yeast (around $2 \%$ ), and drinking water (60-70\%) filtered with activated carbon between $4-5{ }^{\circ} \mathrm{C}$ (GIANNOU; KESSOGLOU; TZIA, 2003) with changes in the percentage of sugar, yeast, and water necessary for reaching the frozen pizza industrial standard (values not shown). The ingredients were weighed on a precision balance with a capacity of 2,000 g, added and mixed in the kneading-trough (except for water) with rod type hook for 1 minute at low speed (level 1). After mixing the dry ingredients, water was incorporated and the dough beat on high speed (level 2) for 6-7 minutes until obtaining a homogeneous, smooth dough with full development of gluten performing the windowpane test" by flattening and stretching the dough with the fingers until it is translucent, resembling a veil. The final temperature of the dough obtained after kneading, recorded with a portable thermometer (skewer, Akso), was around $28^{\circ} \mathrm{C}$ for all repetitions.

After appropriate gluten development, the dough was divided into several portions of approximate weight of $250 \mathrm{~g}$, rounded and fermented according to the experimental design described in section 2.1 .

The pizza dough fermentation was carried out using a industrial scale continuous fermenter. After fermentation, the dough was rolled to a disc of $0.5 \mathrm{~cm}$ thickness and pressed to reach a diameter of $25 \mathrm{~cm} ; 50 \mathrm{~g}$ of tomato sauce were spread over the dough surface. The tomato sauce should be evenly distributed on the surface of the dough before baking to prevent inflating the skin of the dough, which would have the undesired appearance of pita bread. The dough was later taken to prebaking in a Continuous Gas Furnace with volcanic stone at a temperature of $300^{\circ} \mathrm{C}$. After baking, it passed through a freezing tunnel for continuous freezing for 35 minutes until reaching the temperature of $-12^{\circ} \mathrm{C}$. The dough was then packed and sealed in plastic film and subsequently stored at $-18^{\circ} \mathrm{C}$ until analysis.

\subsection{Dough development test and production of carbon dioxide}

The rheology of the dough during fermentation was determined according to the procedure described by Czuchajowska and Pomeranz (1993) and Rossell and Collar (2009) using a CHOPIN F3 rheofermentometer (Tripette \& Renaud, France), which measured the $\mathrm{CO}_{2}$ retention $(\mathrm{mL})$, 
the height of maximum dough development $(\mathrm{Hm}, \mathrm{mm})$, and maximum height of gas release ( $\mathrm{H}^{\prime} \mathrm{m}, \mathrm{mm}$ ).

A portion of dough, prepared as described in sections 2.1 and 2.2, of $315 \pm 0.1 \mathrm{~g}$ was weighed on an electronic precision balance with capacity of $3,000 \mathrm{~g}$ and placed in a mobile perforated fermentation chamber, inserted into the cavity, which was sealed with a lid containing an optical sensor. According to the specification of the equipment, a pressure of two kilograms was applied to the dough using four removable disks of $500 \mathrm{~g}$. The rheofermentometer performed measurements every 6 minutes recording graphically the parameters of dough development and release, or the production or retention of carbon dioxide. The analyses were performed in duplicate on different days.

Ranges of temperature and fermentation time were chosen according to the experimental design described in Section 2.1, and the rheofermentometer analysis was completed as planned, before reaching the height of maximum dough development and gas release, as recommended by the procedure described by Czuchajowska and Pomeranz (1993). To monitor the peak of the dough development parameters and release of carbon dioxide, an experiment was performed to the maximum extent of these parameters, and the analysis was concluded after one hour and a half with the variables of the central point in order to visualize the curves obtained in the equipment.

The parameters obtained using the rheofermentometer were: $\mathrm{Hm}$, which represents the maximum height $(\mathrm{mm})$ of dough development; H'm maximum, the height $(\mathrm{mm})$ of carbon dioxide release; total dough volume $(\mathrm{mL})$; volume of $\mathrm{CO}_{2}$ retention $(\mathrm{mL})$; volume of $\mathrm{CO}_{2}$ lost $(\mathrm{mL})$; and gas retention coefficient (\%).

\subsection{Sensory characterization by Quantitative Descriptive Analysis (QDA)}

For the sensory evaluation of the product under study, the method of Quantitative Descriptive Analysis (QDA) was applied, as described by Stone et al. (1974), Stone and Sidel (1992) and ABNT (ASSOCIATION..., 1998), to identify, describe, and measure the intensity of overall appearance, aroma, taste, and texture perceived in the samples (BATTOCHIO et al., 2006).

\section{Trained sensory panel}

Sensory evaluation of the baked pizza dough was performed by pre-selected trained panelists considering their performance on tests of recognition of basic tastes and aroma and that they have already carried out sensory analysis of this kind of product. The panel was composed of ten panelists with three men and seven women aged 22-44 years. This research project was submitted to the Human Research Ethics Committee of the University (Approval certificate No. 003/2009).

\section{Development of descriptive terminology}

The list of terms or language used for the descriptive sensory analysis of the pizza crust (properly baked dough) was defined based on the traditional network method (DUTCOSKY, 2007) using an attribute form model (GARRUTI et al., 2003) and two sessions to characterize the samples. The panelists received samples of commercial pizza crusts and bread bought from local market to describe the similarities and differences between the samples in terms of appearance, aroma, taste, and texture. The portions of pre- baked frozen crust for each test were heated in a conventional oven at $200{ }^{\circ} \mathrm{C}$ for 10 minutes and served in portions of $30 \mathrm{~g}$ each in a ceramic plate in individual booths.

The samples were presented to the panelists in a monadic way. They were asked to evaluate all samples describing the perceived characteristics of each sample. After each panelist description, a group discussion was held, under the supervision of a leader, with the purpose of grouping similar descriptive terms chosen by consensus by the sensory panel (SANTANA et al., 2006).

In this step, a list of definitions of descriptive terms (attributes) was produced to characterize the samples as well as their definitions and references to determine the minimum and maximum ends of each scale according to Table 1. These are the nine attributes to describe the product: appearance of wood-fired brick oven, surface colour of the edge, presence and bubble size, porosity, aroma and taste of dough, softness, and crispness of the edge.

In addition to the table with the definition of the terms, a sensory evaluation form was used including the selected sensory characteristics of the dough under study. A non-structured 9 $\mathrm{cm}$-scale was used was used anchored on the extremes with terms that expressed intensity (0: lowest intensity; 9 : highest intensity) of appearance, aroma, taste, and texture of pizza crust (LARSEN; SETTER; FAUBION, 1993).

\section{Panelists training}

Ten panelists were submitted to five training sessions on the extremes of the scales for each attribute. The pizza crusts were presented together with the evaluation form. The panel was trained until it proved to be able to evaluate the samples using the evaluation form.

\section{Preparation of samples for sensory evaluation}

The pre-baked pizza dough (three discs of each dough) was thawed at room temperature $\left(\sim 20^{\circ} \mathrm{C}\right)$ for 10 minutes before being prepared. After thawing, the tomato sauce was removed from the surface of the dough with a spoon in order to reduce the influence of its aroma and taste on the baked dough. The entire sample was first evaluated after thawing in terms of appearance, and the attributes smell, taste, and texture were evaluated after the final baking step in a conventional electric oven at $200{ }^{\circ} \mathrm{C}$ for 10 minutes. The definition of this evaluation was based on the fact that the appearance should be assessed prior to final baking in a conventional oven to prevent changing of this attribute during this step. When pizza is baked just before serving, color and texture changes occur, and for that reason, the interest in the present study, was to have an appropriate evaluation of the pre-baked pizza discs that the consumer will buy in supermarkets to finally bake and consume it at home. 
Table 1. Definitions and references of the sensory attributes of pre-baked pizza dough.

\begin{tabular}{|c|c|c|}
\hline Sensory atributes & Definition & References \\
\hline \multicolumn{3}{|l|}{ Appearance } \\
\hline $\begin{array}{l}\text { 1. Appearance of wood-fired } \\
\text { brick oven }\end{array}$ & $\begin{array}{l}\text { Presence of charred spots on the edge } \\
\text { and back of dough }\end{array}$ & $\begin{array}{l}\text { Few = small quantity of charred spots } \\
\text { Too many spots = charred - pizza baked twice in an industrial oven }\end{array}$ \\
\hline 2. Color of the edge & $\begin{array}{l}\text { Intensity of the caramel/gold color on } \\
\text { the surface of the edge }\end{array}$ & $\begin{array}{l}\text { Clear }=\text { clear caramel color }- \text { little baked pizza } \\
\text { Dark = dark caramel color - pizza baked in the oven twice in the } \\
\text { industry }\end{array}$ \\
\hline $\begin{array}{l}\text { 3. Presence of a bubble on the } \\
\text { edge }\end{array}$ & Air lifting on the edge of the dough & $\begin{array}{l}\text { Absent = no air bubbles on the edge of dough - pizza dough without } \\
\text { bubbles } \\
\text { Very = presence of many air bubbles at the edge of dough - pizza dough } \\
\text { with the presence of more than } 10 \text { bubbles on the edge }\end{array}$ \\
\hline 4. Bubble size on the edge & $\begin{array}{l}\text { Predominance of bubble size } \\
\text { (height } \times \text { width) in most pizza }\end{array}$ & $\begin{array}{l}\text { Small bubbles }=10 \times 10 \mathrm{~mm} \\
\text { Large bubbles }=30 \times 30 \mathrm{~mm}\end{array}$ \\
\hline 5. Dough porosity & $\begin{array}{l}\text { Pore structure of the crumb and } \\
\text { edge of the dough }\end{array}$ & $\begin{array}{l}\text { Uneven }=\text { random pores of various sizes }- \text { Italian bread } \\
\text { Dense }=\text { uniform pore structure of the same size }- \text { bread brand Nutrella }\end{array}$ \\
\hline \multicolumn{3}{|l|}{ Aroma } \\
\hline 6. Aroma of dough & $\begin{array}{l}\text { Aroma intensity of dough } \\
\text { (flour + yeast) }\end{array}$ & $\begin{array}{l}\text { Unbaked = aroma of raw dough - unbaked fermented dough } \\
\text { Baked = aroma of baked dough - dough pre-baked and baked in } \\
\text { conventional oven to } 200^{\circ} \mathrm{C} \text { for } 10 \text { minutes }\end{array}$ \\
\hline \multicolumn{3}{|l|}{ Taste } \\
\hline 7. Taste of dough & Taste intensity of dough (flour + yeast) & $\begin{array}{l}\text { Unbaked = taste of raw dough - unbaked fermented dough } \\
\text { Baked = taste of baked dough - dough pre-baked and baked in } \\
\text { conventional oven to } 200^{\circ} \mathrm{C} \text { for } 10 \text { minutes }\end{array}$ \\
\hline \multicolumn{3}{|l|}{ Texture } \\
\hline 8. Softness of the dough & Feeling of lightness & $\begin{array}{l}\text { Little }=\text { little lightness to bite }- \text { pita bread } \\
\text { Much }=\text { much lightness to bite }- \text { bread brand Nutrella }{ }^{\otimes}\end{array}$ \\
\hline 9. Crispness of the edge & Feeling of crispy edge & $\begin{array}{l}\text { Absent = without feeling crunchy to bite - baked dough } \\
\text { Much = great crispness in every bite - dough baked at } 200{ }^{\circ} \mathrm{C} \text { for } \\
15 \text { minutes in conventional oven }\end{array}$ \\
\hline
\end{tabular}

After baking in a conventional oven (Dako ${ }^{\circledR}$, the dough disc was cut into triangular pieces with the approximate weight of $30 \mathrm{~g}$ and served to the judges in ceramic trays within 15-20 minutes due to the rapid changes occurring in the texture after the removal from the oven (LARSEN; SETTER; FAUBION, 1993).

\section{Sensory evaluation}

All sessions of sensory analysis were performed in individual booths under controlled temperature $\left(25 \pm 1{ }^{\circ} \mathrm{C}\right)$ and white light. A randomized complete block design was used using the technique of monadic sequential presentation, i.e., one at a time. The samples were randomly presented to the panel to avoid panelist bias (DUTCOSKY, 2007). The panelists were asked to rate the samples according to the scale proposed in this model of evaluation. Three samples were evaluated in three sessions on different days.

\subsection{Statistical analysis}

The responses of the experimental design for the statistical analysis considering the results obtained by the Chopin rhefermentometer were dough development $(\mathrm{Hm})$ and gas release (H'm). The results were evaluated by analysis of variance (ANOVA) followed by Tukey test ( $\mathrm{p} \leq 0.05)$, using the worksheets for calculating experimental designs available in the website http://lqta.iqm.unicamp.br/portugues/downloads.html.
The QDA results were subjected to analysis of variance (ANOVA) using the Microsoft Office Excel 2007 software (Microsoft Corporation, USA) - Data analysis, as described by Ferreira et al. (2000), Tukey test at 5\% of significance for comparison between averages, and Principal Component Analysis (PCA) that was performed using Statistica 7.0 (Statistica, Statsoft ${ }^{\circledast}$, USA) software. To facilitate visualization of the profile of the samples, a radar chart was built for test comparison (SANTANA et al., 2006).

\section{Results and discussion}

\subsection{Results of the rheological analysis of the dough with rheofermentometer}

In Table 2 shows the average of the responses (y), development of dough $(\mathrm{Hm}, \mathrm{mm})$ and release of carbon dioxide (H'm, mm), and the estimated response $(\hat{\mathbf{y}})$ of the $2^{2}$ factorial design.

There was an unexpected variation in the experimental $\mathrm{Hm}$ values in the central point, which did not occur with the H'm values.

Table 3 shows the effects of the parameters and their interactions with the evaluation of dough development $(\mathrm{Hm})$ and release of carbon dioxide (H'm). 
With regard to the parameter $\mathrm{Hm}$, it was found that no variable showed significant effects for a confidence level of 95\% ( $\mathrm{p} \leq 0.05)$, and in the case of H'm, the effects of time ( $\mathrm{t})$ and temperature $(\mathrm{T})$ influenced significantly and positively the response, but the interaction $\mathrm{t} \times \mathrm{T}$ did not.

Rossell and Collar (2009) obtained a similar result for the development of dough $(\mathrm{Hm}, \mathrm{mm})$ in a study on the effect of temperature and consistency through a quadratic factorial design with three variables evaluating the dough consistency, kneading temperature, and fermentation temperature $\left(15-35^{\circ} \mathrm{C}\right)$ using a basic flour dough, in which the fermentation temperature did present a significant positive effect $(\mathrm{p} \leq 0.05)$ on the development of dough $(\mathrm{Hm}, \mathrm{mm})$. In the same study, the temperature during fermentation significantly affected $(\mathrm{p}<0.001)$ the release of carbon dioxide from the dough $\left(\mathrm{H}^{\prime} \mathrm{m}\right)$ with a positive effect of 31.73 , close to the value obtained in the present study (34.3). Gas retention is a very important point to be considered since it affects directly the structure of the crumb and the volume of the dough (GIANNOU; KESSOGLOU; TZIA, 2003).

The analysis of variance shown in Table 4 indicates that the regression model generated was not significant $\left(\mathrm{F}_{\text {ratio }}\right.$ for regression less than the $\mathrm{F}_{\text {table }}$ ), $\mathrm{R}^{2}$ (coefficient of determination) was 0.882 , showing that the model explained $88.2 \%$ of the experimental data and the lack of fit was not significant $\left(\mathrm{F}_{\text {ratio }}\right.$ for lack of fit smaller than $\mathrm{F}_{\text {table }}$ ), according to Teófilo and Ferreira (2006) and Barros Neto, Scarmini and Bruns (2002).

The analysis of variance presented in Table 5 indicates that the regression model generated was significant (for regression less than the $\mathrm{F}_{\text {table }}$ and still $\mathrm{F}_{\text {ratio }}=10.15 \times \mathrm{F}_{\text {table }}$ ), $\mathrm{R}^{2}$ equal to 0.988 , showing that the model explained $98.8 \%$ of the variation around the mean regression of the experimental data. The lack of fit was not significant $\left(\mathrm{F}_{\text {ratio }}\right.$ for lack of fit smaller than $\left.\mathrm{F}_{\text {table }}\right)$, according to Teófilo and Ferreira (2006) and Barros Neto, Scarmini and Bruns (2002), and it shows that the model is well adjusted to the experimental data, due to the $\mathrm{R}^{2}$ value close to 1 , the regression equation is statistically significant, and low value of lack of fit indicates that the linear model is satisfactory for the studied parameter H'm.

The mean and standard deviation of the results of the selected tests $\mathrm{A}, \mathrm{B}$, and $\mathrm{C}$, measured by the rheofermentometer, are summarized in Table 6, which shows the maximum height of development of the dough $(\mathrm{Hm}, \mathrm{mm})$, maximum height of

Table 2. Response observed and estimated of the development of the dough $(\mathrm{Hm}, \mathrm{mm})$ and release of carbon dioxide (H'm, $\mathrm{mm}$ ).

\begin{tabular}{|c|c|c|c|c|c|c|}
\hline \multicolumn{3}{|c|}{ Design } & \multicolumn{2}{|c|}{$\mathrm{Hm}$} & \multicolumn{2}{|c|}{ H'm } \\
\hline Test & $\mathrm{t}$ (minutes) & $\mathrm{T}\left({ }^{\circ} \mathrm{C}\right)$ & $y$ & $\hat{\mathbf{Y}}$ & $y$ & $\hat{\mathbf{y}}$ \\
\hline 1 & $-1(30)$ & $-1(27)$ & 8.3 & 8.7 & 47.8 & 48.2 \\
\hline 2 & $1(42)$ & $-1(27)$ & 14.9 & 15.3 & 64.0 & 64.4 \\
\hline 3 & $-1(30)$ & $1(33)$ & 13.0 & 13.4 & 79.7 & 80.1 \\
\hline 4 & $1(42)$ & $1(33)$ & 22.9 & 23.3 & 100.7 & 101.1 \\
\hline 5 & $0(36)$ & $0(30)$ & 18.6 & 15.2 & 76.3 & 73.5 \\
\hline 6 & $0(36)$ & $0(30)$ & 15.0 & 15.2 & 75.0 & 73.5 \\
\hline 7 & $0(36)$ & $0(30)$ & 13.6 & 15.2 & 70.8 & 73.5 \\
\hline
\end{tabular}

$(\mathrm{Hm})=$ maximum height of development of the dough $\left(\mathrm{H}^{\prime} \mathrm{m}\right)=$ maximum height of release of carbon dioxide. $y=$ obtained response; $\hat{y}=$ estimated response. release of carbon dioxide (H'm, $\mathrm{mm})$, the total volume $(\mathrm{mL})$, retention volume $(\mathrm{mL})$ volume of gas release $(\mathrm{mL})$, and retention coefficient (\%).

Data analysis indicate that tests A and B showed similar results in the parameters $\mathrm{Hm}(\mathrm{mm})$, total volume, and retention volume; which was not observed for test $\mathrm{C}$ that showed higher values for development of dough and total and retention volumes. As shown in Table 6, there are increasing H'm $(\mathrm{mm})$ values from test $\mathrm{A}$ to $\mathrm{C}$.

There was no increase between the parameters comparing the trials A and B in relation to dough development indicating that by increasing temperature and reducing time, similar results were found for temperatures of $27^{\circ} \mathrm{C}$ and of $30^{\circ} \mathrm{C}$, reaching a maximum development (maximum dough height) similar to those of doughs with development time of 42 minutes $(\mathrm{Hm}=14.9 \mathrm{~mm})$ and 36 minutes $(\mathrm{Hm}=16.1 \mathrm{~mm})$.

Test $\mathrm{C}$ showed results with an increase in height in the development of dough $(\mathrm{Hm}=22.9 \mathrm{~mm})$. With regard to data

Table 3. Estimated effect, standard error, and level of statistical significance (p) for Hm and H'm.

\begin{tabular}{|c|c|c|c|c|c|c|c|}
\hline \multicolumn{2}{|c|}{ Parameters } & \multicolumn{3}{|c|}{$\mathrm{Hm}$} & \multicolumn{3}{|c|}{ H'm } \\
\hline Variable & & Effect & & Error & Effect & & Error \\
\hline & Average & 15.19 & \pm & 0.97 & 73.47 & \pm & 1.09 \\
\hline $\mathrm{T}$ & 1 & 8.25 & \pm & 2.58 & $18.00^{*}$ & \pm & 2.87 \\
\hline $\mathrm{T}$ & 2 & 6.35 & \pm & 2.58 & $34.30^{*}$ & \pm & 2.87 \\
\hline $\mathrm{t} \times \mathrm{T}$ & 12 & 1.65 & \pm & 2.58 & 2.40 & \pm & 2.87 \\
\hline \multicolumn{7}{|c|}{ Significance level $\alpha$ : } & 0.05 \\
\hline
\end{tabular}

$\hat{y}=b_{0}+b_{1} x_{1}+b_{2} x_{2} ; x_{1}=t$ and $x_{2}=T$.

$(\mathrm{t})=$ time $\left(\right.$ minutes) and $(\mathrm{T})=$ temperature $\left({ }^{\circ} \mathrm{C}\right)$.

$\left.{ }^{*}\right) \mathrm{p} \leq 0.05$

Table 4. Analysis of Variance (ANOVA) for development of dough (Hm, mm).

\begin{tabular}{lrrrrrr}
\hline \multicolumn{1}{c}{ Source } & SS & DF & MS & Fratio & Ftable & p-value \\
\hline $\begin{array}{l}\text { Regression } \\
\text { coefficient }\end{array}$ & 111.107 & 3 & 37.036 & 7.467 & 9.28 & 0.0667 \\
$\begin{array}{l}\text { Residue } \\
\text { Lack-of-fit }\end{array}$ & 14.881 & 3 & 4.961 & & & \\
$\begin{array}{l}\text { Pure Error } \\
\text { Total }\end{array}$ & 1.574 & 1 & 1.575 & 0.237 & 18.51 & 0.675 \\
\% variance explained & 125.989 & 6 & 6.654 & & & \\
\% maximum variance explained & 89.438 & & & & \\
\hline
\end{tabular}

Table 5. Analysis of Variance (ANOVA) for gas release (H'm).

\begin{tabular}{lrccccc}
\hline \multicolumn{1}{c}{ Source } & \multicolumn{1}{c}{ SS } & DF & MS & Fratio & Ftable & p-value \\
\hline $\begin{array}{l}\text { Regression } \\
\text { coefficient }\end{array}$ & 1528.210 & 3 & 509.403 & 84.040 & 8.28 & 0.002 \\
Residue & 18.184 & 3 & 6.061 & & & \\
Lack-of-fit & 1.658 & 1 & 1.658 & 0.201 & 18.51 & 0.698 \\
Pure Error & 16.527 & 2 & 8.263 & & & \\
Total & 1546.394 & 6 & & & & \\
\% variance explained & & 98.82408 & & & \\
\% maximum variance explained & 98.93128 & & & \\
\hline
\end{tabular}

$\left.{ }^{*}\right)$ Significant $(\mathrm{p} \leq 0,05)$ 
of carbon dioxide release, it was observed that the higher the fermentation temperature, the higher the gas release.

Analyzing the results of peak height (Hm, and H'm), time (T1, T'1 and Tx), volumes, and the curves of development of dough and gas release of the complete cycle of the rheofermentometer for the pizza dough with time and temperature of the test (Figure 1), it was found that the maximum development of

Table 6. Mean responses $(n=2)$ of the rheofermentometer in relation to volume during fermentation of selected experimental levels.

\begin{tabular}{|c|c|c|c|}
\hline \multirow{2}{*}{ Test } & A & B & $\mathrm{C}$ \\
\hline & \multicolumn{3}{|c|}{ Mean \pm Standard deviation } \\
\hline $\mathrm{Hm}(\mathrm{mm})$ & $15.0 \pm 0.2$ & $16.1 \pm 3.5$ & $22.9 \pm 1.9$ \\
\hline H’m (mm) & $64.0 \pm 0.5$ & $73.6 \pm 3.8$ & $101.0 \pm 9.3$ \\
\hline Total volume (mL) & $228.0 \pm 5.7$ & $229.5 \pm 33.2$ & $374.0 \pm 36.8$ \\
\hline Retention volume (mL) & $227.5 \pm 4.9$ & $228.0 \pm 32.5$ & $372.0 \pm 36.8$ \\
\hline Volume of gas release $(\mathrm{mL})$ & $3.0 \pm 1.4$ & $2.0 \pm 0$ & $1.5 \pm 0.7$ \\
\hline Retention coefficient (\%) & $98.6 \pm 0.9$ & $99.2 \pm 0$ & $99.5 \pm 0.1$ \\
\hline
\end{tabular}

$(\mathrm{Hm})=$ maximum height of development of the dough $\left(\mathrm{H}^{\prime} \mathrm{m}\right)=$ maximum height of release of carbon dioxide. $\mathrm{A}=(+1 ;-1) ; \mathrm{B}=(0 ; 0) ; \mathrm{C}=(+1 ;+1)$. the dough (T1) occurred after 1 hour and 46 minutes with the maximum height ( $\mathrm{Hm}, \mathrm{mm}$ ) of $55.1 \mathrm{~mm}$, and the maximum time of gas release ( $\left.T^{\prime} 1\right)$ was after 1 hour and 27 minutes with maximum height (H'm) of $114.8 \mathrm{~mm}$ and time of gas loss (Tx) of 1 hour and 04 minutes. A similar result in the development of dough (Hm, mm) was obtained by Angioloni, Berti and Rose (2004), with a value of $50.47 \mathrm{~mm}$, in a study performed with three types of flour for pizza dough using a rheofermentometer with the goal of decreasing mixing time.

\subsection{Quantitative Descriptive Analysis (QDA) results}

For the data analysis, a double-factor analysis of variance (ANOVA) with repetition was used for each attribute, as shown in Table 7, based on Ferreira et al. (2000). For all analyses, when $\mathrm{P}_{\text {panelist }}$ value was considered $\geq 0.05$, the panel responses did not differ statistically among themselves on a $5 \%$ significance level. To verify the difference between the samples, the values $\mathrm{F}$ and $\mathrm{F}_{\text {critical }}$ were compared, and if $\mathrm{F}_{\text {sample }}>\mathrm{F}_{\text {critical }}$, the samples differed from each other. To evaluate whether the panel results followed the same trend, it was considered the parameter $\mathrm{P}_{\text {interactions }} \geq 0.05$. If $\mathrm{P}_{\text {interactions }} \leq 0.05$, it would produce at least one

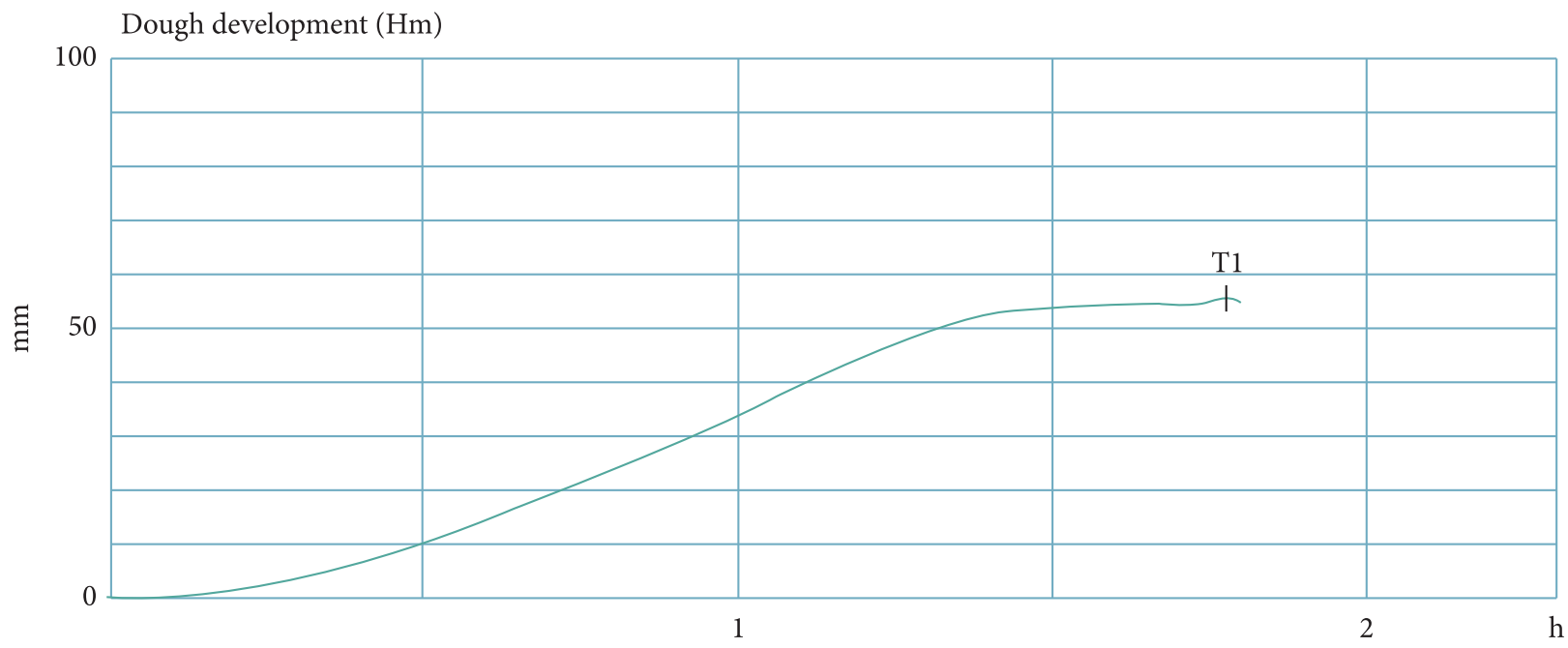

Release of carbon dioxide

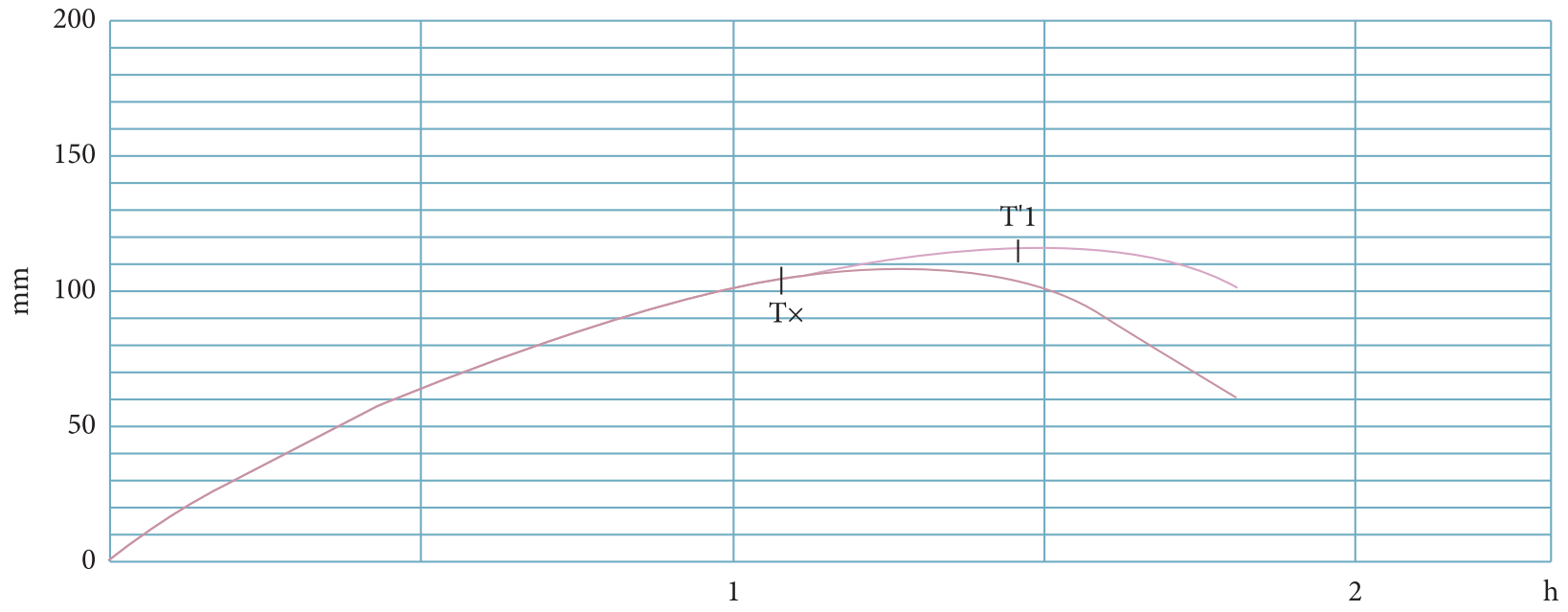

Figure 1. Rheofermentograms of the tested samples. 
wrong answer (there was no consensus) among the panelists, and thus a trend graph was built for each attribute (not shown in this paper); and if found that one panelist response did not follow the same trend, it would be excluded, and the ANOVA would be recalculated.

The results of the mean values for each attribute after the Tukey test for the significant values in the ANOVA $\left(\mathrm{P}_{\text {sample }}<0.05\right)$ are presented in Table 7.

The profiles of each test (samples) submitted to the sensory analysis are shown graphically in Figure 2, in which the mean value assigned by the panelist for each attribute is marked in the

Table 7. Mean values of sensory attributes that characterize the pizza dough samples.

\begin{tabular}{lccc}
\hline \multicolumn{1}{c}{ Attribute/Sample } & A & B & C \\
\hline Appearance of wood-fired brick oven & $6.43^{\mathrm{b}}$ & $7.35^{\mathrm{a}}$ & $5.30^{\mathrm{c}}$ \\
Surface color of the edge & $5.55^{\mathrm{a}}$ & $4.37^{\mathrm{b}}$ & $5.18^{\mathrm{ab}}$ \\
Presence of a bubble on edge & $3.95^{\mathrm{c}}$ & $7.32^{\mathrm{a}}$ & $6.37^{\mathrm{b}}$ \\
Bubble size on the edge & $7.54^{\mathrm{a}}$ & $4.93^{\mathrm{b}}$ & $4.38^{\mathrm{c}}$ \\
Dough porosity & $0.47^{\mathrm{b}}$ & $1.57^{\mathrm{a}}$ & $1.53^{\mathrm{a}}$ \\
Aroma of dough & $6.08^{\mathrm{a}}$ & $6.54^{\mathrm{a}}$ & $6.48^{\mathrm{a}}$ \\
Taste of dough & $6.18^{\mathrm{a}}$ & $6.55^{\mathrm{a}}$ & $6.51^{\mathrm{a}}$ \\
Softness of dough $^{\star *}$ & $3.47^{\mathrm{a}}$ & $3.02^{\mathrm{a}}$ & $3.89^{\mathrm{a}}$ \\
Crispness of the edge $^{*}$ & $6.66^{\mathrm{a}}$ & $6.96^{\mathrm{a}}$ & $6.87^{\mathrm{a}}$ \\
\hline
\end{tabular}

a,b,c Means with the same letter(s) in the line are not significantly different at $5 \%$ significance level according to Tukey test; ${ }^{*}$ Means with nine panelists; ${ }^{* *}$ Means with eight panelists Means without ${ }^{*}$ represent 10 panelists; Scale: $0-9 \mathrm{~cm}$ corresponding axis. The center of the figure represents the zero point of the scale used in evaluation, while intensity increases from the center towards the periphery, and the sensory profile is thus revealed when the points are connected (GARRUTI et al., 2003).

It was observed that sample A has distinguished itself from the others by having more pronounced bubble size and uneven porosity showing interaction between the two attributes and similarity to sample $C$ in the attribute color of the edge. It is noteworthy that the porosity is not uniform, and that is a positive characteristic for pizza dough that should have large and small bubbles indicating a kind of rustic/artisanal bread baked in wood-fired brick oven. Sample B is stands out in the attribute presence of bubble on the edge, and it showed a pattern similar to sample $\mathrm{C}$ regarding the attributes color of the edge and surface porosity. The three samples differ in the attributes appearance of wood-fired brick oven, and presence of bubble and bubble size. There was no significant difference $(p \geq 0.05)$ in the attributes aroma and taste, softness of dough, and crispness of the edge.

The data analysis showed that the samples B and C had abundant medium size bubbles on the edge, aroma and taste of baked dough and moderate softness and crispy edges characteristic of pizza crust. These differences are probably related with the time - temperature combination that slightly altered the dough rheology.

For the Principal Component Analysis (PCA), the results of three repetitions of each panelist and the attributes that were significant in the ANOVA were used; thus, the attributes aroma

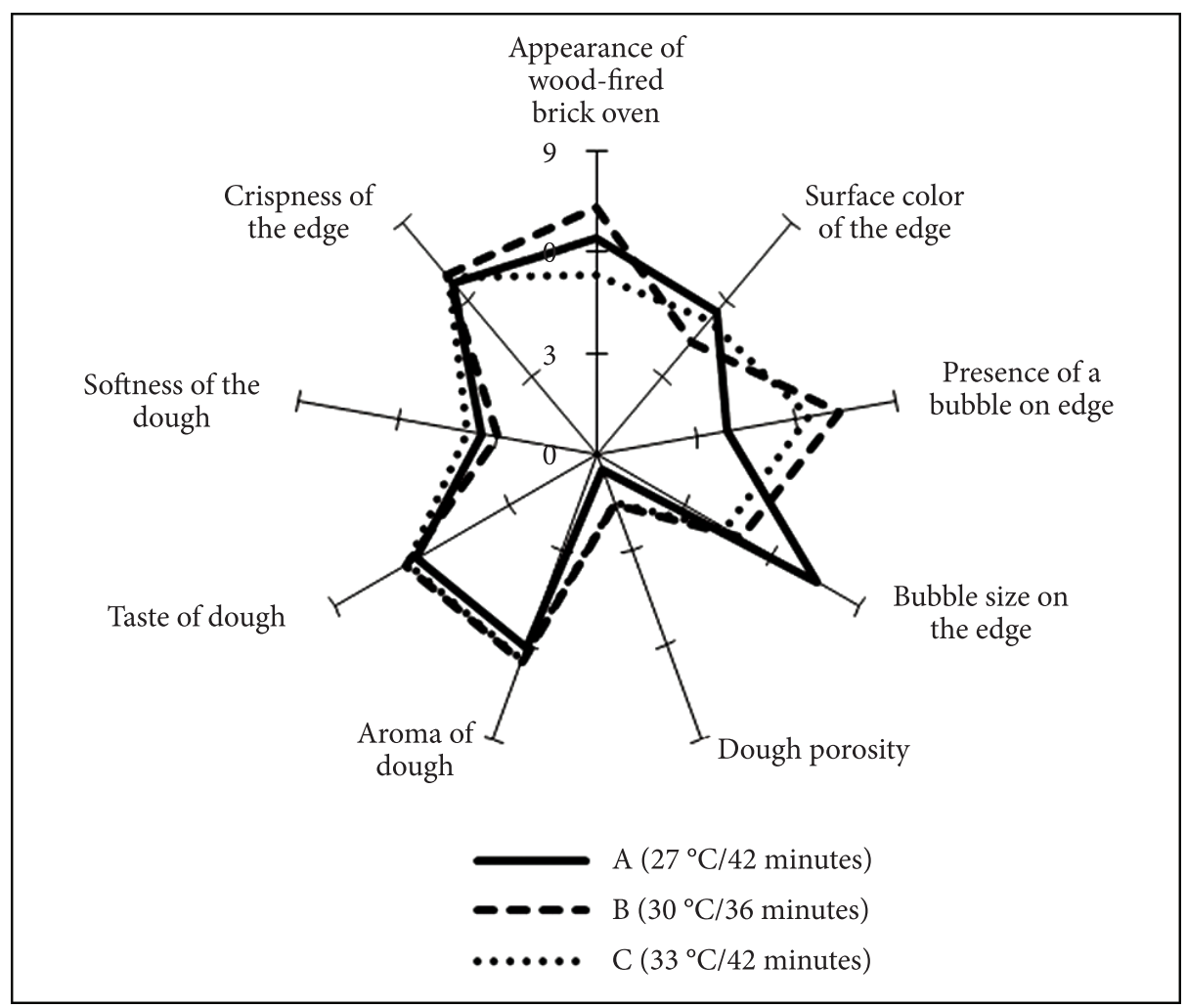

Figure 2. Sensory profile radar chart for the pizza dough samples. 


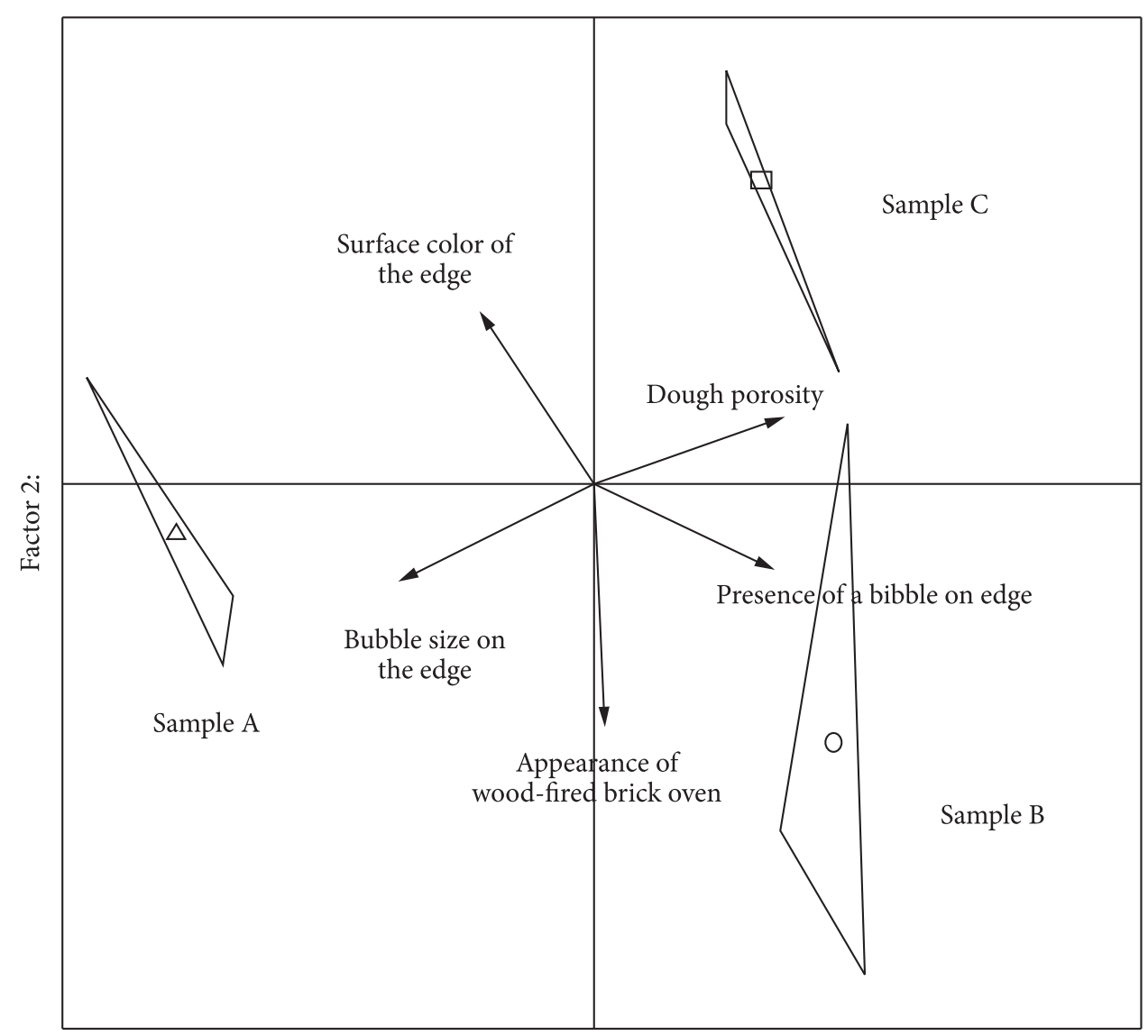

Factor 1: 44,75\%

Figure 3. Analysis of bidimensional projection of the Principal Component Analysis of the descriptive terms of pizza dough.

and taste of dough and softness and crispness of the dough edge (not significant at 5\%) were removed from the PCA. To choose the representative major components, a correlation matrix was used, in which the factors 1 and 2 explained $71.51 \%$ of total data variability.

Figure 3 shows the PCA graph; the results of each sample of pizza dough and the repetitions are indicated by three connected points forming a triangle. Each vertex of the triangle corresponds to the point of the replications attributed by the sensory panel (SANTANA et al., 2006). The samples are characterized by the attributes represented in the figure by the vectors that appear next to them. In this type of graph, the higher the decomposition of the vector on the axes of the components, the greater the need to characterize the differences of the samples (GARRUTI et al., 2003). Therefore, sample A showed higher intensity in bubble size on the edge and uneven porosity of the dough in a scale defined according to the sensory panel. Uneven porosity is an interesting characteristic for pizza dough that presents different size pores/bubbles. Sample B was characterized by the appearance of wood-fired brick oven baked, presence of bubbles in the dough, and porosity of the dough; sample $\mathrm{C}$ was characterized by porosity of dough.

It was observed that Factor 1 explains $44.75 \%$ of the results variability, and is represented by most of the analyzed attributes, while factor 2 explains $26.76 \%$ of the data variability. The attributes that represent the first factor are presence (0.79) and bubble size $(-0.83)$ on the edge, and the porosity $(0.85)$; and those that represent the second factor are appearance of wood-fired brick oven baked (0.85) and color of the edge (0.60).

When the results of the quantitative descriptive analysis of pizza dough underwent Principal Component Analysis (PCA), the sensory characteristics of each sample were observed showing very good agreement with the results obtained by the ANOVA and the radar chart analyses.

\section{Conclusion}

According to the fermentation parameters of the pizza dough evaluated using a rheofermentometer under the conditions of the selected experimental design, time (t) and temperature $(\mathrm{T})$ were the significant linear factors for carbon dioxide release (H'm, $\mathrm{mm})$, but not for the development of dough (Hm, mm).

According to the $\mathrm{QDA}$ and $\mathrm{PCA}$ results, samples $\mathrm{B}$ ( $30^{\circ} \mathrm{C} / 36$ minutes) and $\mathrm{C}\left(33^{\circ} \mathrm{C} / 42\right.$ minutes $)$ showed bubble size, aroma, and taste of baked dough, and crispy edges, which are desired pizza crust characteristics. 
The reduction time of fermentation (30\% if 1 hour is considered) allowed producing good quality pizza dough with significant production time savings, which represents important cost reduction in the industry, and the product had similar and desired sensory quality if compared with the product made by conventional fermentation process that takes around 1 to 1 hour and 30 minutes.

\section{Aknowledgements}

The authors are grateful to Bunge Alimentos S.A. for allowing the use of the rheofermentometer.

\section{References}

ANGIOLONI, A.; BERTI, C.; ROSA, M. D. Messa a punto di um preparato per ottenere impasti tipo pizza in brevissimi tempi di miscelazione. Industrie Alimentari, v. 42, n. 442, p. 12811285, 2004.

ASSOCIAÇÃO BRASILEIRA DE NORMAS TÉCNICAS - ABNT. NBR 14140: Alimentos e Bebidas - Análise sensorial - Teste de análise descritiva quantitativa (ADQ). ABNT, 1998.

AUTIO, K.; LAURIKAINEN, T. Relationships between flour/dough microstructure and dough handling and baking properties. Trends in Food Science \& Technology, v. 8, p. 181-185, 1997. http://dx.doi. org/10.1016/S0924-2244(97)01039-X

BRASIL. Ministério de Agricultura Pecuária e Abastecimento. Associação Brasileira da Indústria e Massas Alimentícias. Instrução normativa $\mathrm{n}^{\circ} 8$, de 2 de junho de 2005. Regulamento técnico de identidade e qualidade de farinha de trigo. Diário Oficial da República Federativa do Brasil, Brasília, DF, 3 jun. 2005. Seção 1, n. 105, p. 91. Disponível em: <http://www.abima.com. br/dload/13_44_instr_norm_8_05_leg_alim_nac.pdf $>$. Acesso em: 20 jan. 2010.

BARROS NETO, B.; SCARMINIO, I. S.; BRUNS, R. E. Como fazer experimentos: pesquisa e desenvolvimento na ciência e na indústria. Campinas: UNICAMP, 2002. p. 223-227, 261-262.

BATTOCHIO, J. R. et al. Perfil sensorial de pão de forma integral. Ciência Tecnologia de Alimentos, v. 26, n. 2, p. 428-433, 2006. http://dx.doi.org/10.1590/S0101-20612006000200028

COPPOLA, S.; PEPE, O.; MAUREIELLO, G. Effect of leavening microflora on pizza dough properties. Journal of Applied Microbiology, v. 85, p. 891-897, 1998. http://dx.doi.org/10.1046/ j.1365-2672.1998.00570.x

CLARKE, C. H.; FARRELL, G. The effects of recipe formulation on the textural characteristics of microwave-reheated pizza bases. Journal of the Science of Food and Agriculture, v. 80, p.1237-1244, 2000. http://dx.doi.org/10.1002/1097-0010(200006)80:8<1237::AIDJSFA630>3.0.CO;2-8

CZUCHAJOWSKA, Z.; POMERANZ, Y. Gas formation and gas retention.I.The system and methodology. Cereal Foods World, v. 38, p. 499-503, 1993.
DOBRASZCZYK, B. J.; MORGENSTERN, M. P. Rheology and breadmaking process. Journal of Cereal Science, v. 38, p. 229245, 2003. http://dx.doi.org/10.1016/S0733-5210(03)00059-6

DUTCOSKY, S. A. Análise Sensorial de Alimentos. Editora Champagnat, 2007. p. 123-180

FERREIRA, V. L. P. et al. Análise sensorial testes descritivos e afetivos. PROFIQUA; SBCTA, 2000. p. 92-94, 97-98. (Manual - Série Qualidade).

FORMATO, A.; PEPE, O. Pizza dough differentiation by principal component analysis of alveographic, microbiological, and chemical parameters. Cereal Chemistry, v. 82, n. 4, p. 356-360, 2005. http:// dx.doi.org/10.1094/CC-82-0356

GAN, Z.; ELLIS, P. R.; SCHOFIELD, J. D. Mini review gas cell stabilization and gas retention in wheat bread dough. Journal of Cereal Science, v. 21, p. 215-230, 1995. http://dx.doi.org/10.1006/ jcrs. 1995.0025

GARRUTI, D. S. et al. Desenvolvimento do perfil sensorial e aceitação de requeijão cremoso. Ciência e Tecnologia de Alimentos, v. 23, n. 3, p. 434-440, 2003.

GIANNOU, V. K.; KESSOGLOU, V.; TZIA, C. Quality and safety characteristics of bread made from frozen dough. Trends in Food \& Technology, v. 14, p. 199-108, 2003.

LARSEN, D. M.; SETTER C. S.; FAUBION, J. M. Effects of flour type and dough retardation time on the sensory characteristic of pizza crust. Cereal Chemistry, v. 70, n. 6, p. 647-650, 1993.

PINHO, B. H. S.; MACHADO, M. I.; FURLONG, E. B. Propriedades físico-químicas das massas de pizza semiprontas e sua relação com o desenvolvimento de bolores e leveduras. Revista Instituto Adolfo Lutz, v. 60, n. 1, p. 35-41, 2001.

ROSELL, C. M.; COLLAR, C. Effect of temperature and consistency on wheat dough performance. International Journal of Food Science and Technology, n. 44, p. 493-502, 2009. http://dx.doi. org/10.1111/j.1365-2621.2008.01758.x

SANTANA, L. R. R. et al. Perfil sensorial de iogurte light, sabor pêssego. Ciências e Tecnologia de Alimentos, v. 26, n. 3, p. 619-625, 2006. http://dx.doi.org/10.1590/S0101-20612006000300021

SCANLON, M. G.; ZGHAL, M. C. Bread properties and crumb structure. Food Research International, v. 34, p. 841-864, 2001. http://dx.doi.org/10.1016/S0963-9969(01)00109-0

STONE, H.; SIDEL, J. L. Sensory Evaluation Practices. 2. ed. San Diego: Academic Press, 1992. 308 p.

STONE, H. et al. Sensory evaluation by Quantitative Descriptive Analysis. Food Technology, v. 28, n. 11, p. 24-34, 1974.

TEÓFILO, R. F.; FERREIRA, M. M. Quiometria II: Planilhas eletrônicas para cálculos de planejamentos experimentais, um tutorial. Química Nova, v. 29, n. 2, p. 338-350, 2006.

WANG, S. H. et al. Farinhas de trigo e soja pré-cozidas por extrusão para massas de pizza. Pesquisa Agropecuária Brasileira, v. 40, n. 4, 2005. 